\title{
Decrease of Antibodies to Insulin, Proinsulin and Contaminating Hormones after Changing Treatment from Conventional Beef to Purified Pork Insulin
}

\author{
A. B. Kurtz, J. A. Matthews, B. E. Mustaffa, P. R. Daggett, and J. D. N. Nabarro \\ Department of Nuclear Medicine and Cobbold Laboratories, Thorn Institute of Clinical Science, The Middlesex Hospital Medical School, \\ London, England
}

\begin{abstract}
Summary. The sera of 30 patients who had been treated with conventional beef insulin were tested for binding of insulin and other pancreatic hormones. All showed antibody binding of insulin, 29 binding of proinsulin, 29 binding of pancreatic polypeptide, two binding of glucagon but none of the sera bound vasoactive intestinal peptide or somatostatin. After changing therapy to highly purified pork insulin the binding capacity of sera for insulin and the other hormones was monitored for up to 35 months and a steady fall was found in nearly all cases. In eight of the patients conventional beef insulin treatment was resumed: in one month binding of insulin and of the other hormones increased back to the initial levels. In eighteen subjects who had only received highly purified pork insulin low levels of insulin binding were found with no binding of proinsulin or other hormones. The amounts of proinsulin and contaminating hormones in highly purified pork insulin are so low that they are not immunogenic; conventional beef insulin not only contains immunogenic amounts of proinsulin and the contaminating hormones pancreatic polypeptide and glucagon but also is more immunogenic than purified pork insulin.
\end{abstract}

Key words: Insulin, proinsulin, pancreatic polypeptide, glucagon, antibodies.

Conventional beef insulin preparations are more immunogenic than highly purified pork insulin [1]. They contain appreciable quantities of proinsulin, pancreatic polypeptide (PP), glucagon, somatostatin and vasoactive intestinal peptide (VIP) [2]. The greater immunogenicity of the conventional beef insulins has been attributed to the contaminants although other factors such as alteration or polymerisation of the insulin may be more important. A change of therapy from beef to purified pork insulin involves both a change in the species of insulin origin and an increase in purity as well as a possible change in the physical or chemical state of the insulin.

In the present study the antibodies to insulin, proinsulin, PP, glucagon, somatostatin and VIP have been measured in patients treated with conventional beef insulin before and at intervals after a change to highly purified pork insulin.

\section{Materials and Methods}

\section{Patients}

Thirty insulin treated patients were studied; 17 males and 13 females with an average age at the start of the study of 33 years (range 12-67) and an average duration of diabetes of 12 years (range 5-38).

For at least six months before the start of this study all the patients were treated with twice daily soluble and isophane beef insulin with an average daily dose of $55 \mathrm{U}$ (range 24-84): before this some had received other beef insulin preparations including beef/pork mixtures. None of the patients were regarded as "brittle" or insulin resistant, their antibody status was not known when they entered this study and none were taking immunosuppressive drugs or steroids.

An initial blood sample was collected and then, after changeover to highly purified pork insulin (twice daily Leo Neutral $^{(\mathbb{B}}$ and Leo Retard ${ }^{\sqrt{\widehat{A}}}$ insulins), blood samples were collected at approximately monthly intervals for six months and thereafter at 4-6 monthly intervals. The group was followed for an average of 30 months (range 23-35): twenty two patients have continued on the purified pork insulin while eight patients, at their own request, have changed back to conventional beef insulin after an average of 8.4 months (range 6-12) on the purified pork insulin.

For comparison with this group of patients the sera from 18 subjects never treated with other than highly purified pork insulin were checked for antibody binding. This group had been on insulin for an average of 13 months (range 2-24). 
Table 1. Serum binding of different ligands (as mean \pm SEM). Column A gives values for 30 subjects treated with conventional beef insulin and column $B$ values for the same subjects for the final sample while on purified pork insulin. For the differences between the values in columns $\mathrm{A}$ and $\mathrm{B} p<0.001$. In column $\mathrm{C}$ values are given for 18 subjects only treated with purified pork insulin. Results are given as \% ligand bound minus the non-specific binding (see Methods)

\begin{tabular}{|c|c|c|c|}
\hline Ligand & $\begin{array}{l}\mathrm{A} \\
\%\end{array}$ & $\begin{array}{l}\mathrm{B} \\
\%\end{array}$ & $\begin{array}{l}\mathrm{C} \\
\%\end{array}$ \\
\hline Beef insulin & $15.4 \pm 2.0$ & $8.5 \pm 1.7$ & $6.7 \pm 1.6$ \\
\hline Pork insulin & $10.8 \pm 1.6$ & $4.8 \pm 1.2$ & $5.0 \pm 1.5$ \\
\hline Beef proinsulin & $16.6 \pm 3.0$ & $7.7 \pm 1.9$ & $-0.1 \pm 0.2$ \\
\hline Pork proinsulin & $14.3 \pm 3.1$ & $7.5 \pm 2.2$ & $-0.4 \pm 0.1$ \\
\hline $\begin{array}{l}\text { Pancreatic poly- } \\
\text { peptide }\end{array}$ & $16.5 \pm 2.6$ & $2.9 \pm 0.8$ & $0.1 \pm 0.1$ \\
\hline
\end{tabular}

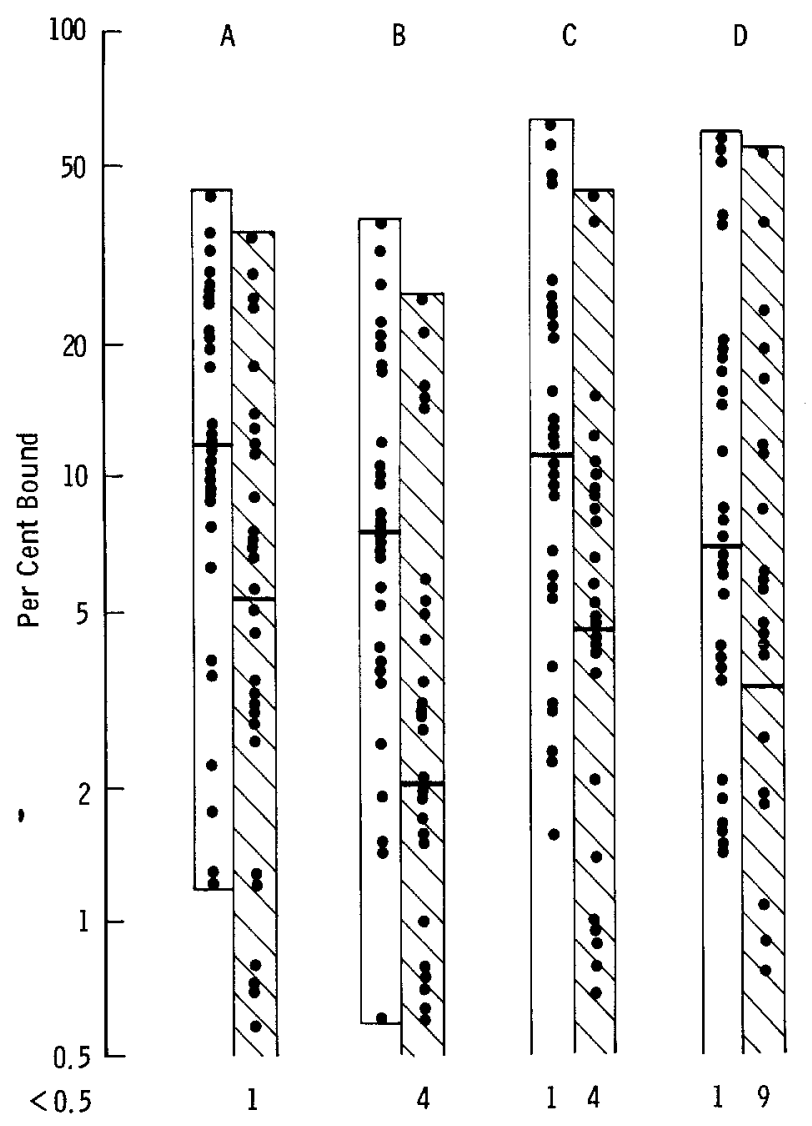

Fig. 1. Beef Insulin (A), Pork Insulin (B), Beef Proinsulin (C) and Pork Proinsulin (D) binding by sera from 30 subjects. The open columns show the initial values, when on conventional beef insulin, and the shaded columns the values for the final samples collected when receiving purified pork insulin. The horizontal bars indicate median values. Results are given as \% binding of ligand minus non-specific binding (see methods)

\section{Assay Methods}

Blood samples were collected at routine diabetic clinic visits and the plasma or serum stored deep-frozen until studied.

For all the ligands tested the same general method was used to measure antibody binding. Ten $\mu \mathrm{l}$ of plasma was incubated for $24 \mathrm{~h}$ at $4^{\circ} \mathrm{C}$ with $150 \mu \mathrm{l}$ of $0,04 \mathrm{~mol} / 1$ sodium phosphate buffer, $\mathrm{pH} 7.5$, containing sodium chloride $0.15 \mathrm{~mol} / \mathrm{l}$, bovine serum albumin $0.5 \mathrm{~g} / \mathrm{l}$, bovine gamma globulin $0.25 \mathrm{~g} / 1$ and ${ }^{125} \mathrm{I}$ labelled ligand, approximately $200,000 \mathrm{cpm} / \mathrm{ml}$. Then followed the addition of $1.5 \mathrm{ml}$ of ice cold $0.05 \mathrm{~mol} / \mathrm{l}$ veronal buffer, $\mathrm{pH} 8.6$, containing polyethylene glycol $6000,150 \mathrm{~g} / 1$, and Tween $20,1 \mathrm{~g} / \mathrm{l}$. The precipitate, containing bound ligand, was separated by centrifugation at $1500 \mathrm{~g}$ for $30 \mathrm{~min}$ at $4^{\circ} \mathrm{C}$. After aspiration of the supernatant the precipitate was washed with $1.5 \mathrm{ml}$ of ice cold veronal buffer containing polyethylene glycol $6000,125 \mathrm{~g} / 1$, and Tween $20,1 \mathrm{~g} / 1$, centrifuged again, and the radioactivity counted.

Highly purified beef and pork insulins labelled with ${ }^{125} \mathrm{I}$ were provided by Novo Laboratories Ltd. Beef and pork proinsulins (provided by Novo Laboratories Ltd.) were labelled with ${ }^{125} \mathrm{I}$ by means of solid-phase lactoperoxidase [3] and purified on cellulose columns (Whatman CF11) [4]. In the determination of proinsulin binding insulin-binding antibody was blocked by including highly purified pork insulin in the incubation buffer at a concentration of $6.7 \mathrm{U} / \mathrm{ml}[5]$

Pork pancreatic polypeptide (provided by Novo Laboratories Ltd.) was ${ }^{125}$ I labelled by means of solid-phase lactoperoxidase and purified on a sephadex G-100 column.

Pork glucagon labelled with ${ }^{125} \mathrm{I}$ was provided by Novo Laboratories Ltd. and somatostatin and VIP labelled with ${ }^{125} \mathrm{I}$ were provided by Nordisk Diagnostics Ltd. In the determination of glucagon, somatostatin and VIP binding aprotinin $40 \mathrm{mg} / 1$ was added to the incubation buffer. The specific activity of the labelled insulins was approximately $25 \mu \mathrm{Ci} /$ ug and of the other labelled hormones approximately $100 \mu \mathrm{Ci} /$ ug.

Results are expressed as the percent of ligand bound minus the non-specific binding which ranged in different assays from $0.8-2.0 \%$ for pork and beef insulins, $2.0-4.7 \%$ for pork and beef proinsulins, $1.7-4.4 \%$ for $\mathrm{PP}, 2.0-2.5 \%$ for somatostatin, $2.4-2.5 \%$ for glucagon and $6-9 \%$ for VIP. All the samples from an individual patient were assayed at the same time. For these assays the within assay coefficient of variation was less than $2.5 \%$ : for insulin the between assay coefficient of variation was $7.1 \%$.

The significance of the results was tested with Student's t test using the paired t-test where appropriate.

\section{Results}

Sera from all 30 subjects contained insulin binding antibody, 29 showed proinsulin binding and PP binding, and two had glucagon binding. No antibody binding of somatostatin or VIP was detected in any of the sera. Table 1 and Figure 1 show the antibody binding for samples collected at the start of the study, when the patients were on conventional beef insulin, and for the last sample collected while the patients were on highly purified pork insulin. Comparing these results 26 out of 30 subjects showed a fall of antibody capacity for beef insulin, 29 out of 30 for pork insulin, 28 out of 29 for beef proinsulin, 26 out of 29 for pork proinsulin, 29 out of 29 for pancreatic polypeptide, and 2 out of 2 for glucagon.

When the patients were changed from conventional beef insulin to purified pork insulin there was a $13 \%$ fall in the average daily insulin dose, from $55 \mathrm{U}$ to $48 \mathrm{U}$ (range 24-75: $\mathrm{p}<0.001$ ).

In the eight subjects who changed back to conventional beef insulin there were increases in binding 
to levels that were not significantly different, for insulin, proinsulin or contaminating hormones, from the initial values. This response is shown for pancreatic polypeptide in Figure 2 and for glucagon in Figure 3.

For the 18 patients only ever treated with purified pork insulin the mean ( \pm SEM) binding of beef insulin was $6.7 \% \pm 1.6$ (range $0.5-19.5 \%$ ) and pork insulin was $5.0 \% \pm 1.5$ (range $0.2-13.7 \%$ ). In this group antibody binding of proinsulin, pancreatic polypeptide, glucagon, somatostatin and VIP could not be detected.

\section{Discussion}

The method of antibody measurement which we have used is based upon a polyethylene glycol separation of bound and free labelled ligand [6]. It is sufficiently sensitive for small serum samples to be used and has low non-specific binding with most hormones: for insulin antibody the detection limit is an antibody binding site concentration of approximately $50 \mathrm{mU} / \mathrm{l}$. We have expressed the result as percent binding (B) which for comparative and clinical purposes is satisfactory - the term $\mathrm{B} /(100-\mathrm{B})$ is proportional to the equilibrium constant $(\mathrm{K})$ multiplied by the concentration of unoccupied binding sites $(\mathrm{Q})$. A wide range of values for $B$ is found, from no detectable antibody when $\mathrm{B}$ is about $1 \%$ to antibody mediated insulin resistance when $\mathrm{B}$ is about $80 \%$, with good precision over the whole range. The disadvantage of this method is that the value $B$ is affected by changes of tracer specific activity so that it is best to include all samples from serial studies in a single assay. We have used labelled hormones with specific activities in the range of $25-100 \mu \mathrm{Ci} / \mu \mathrm{g}$. This method is versatile and can be used for other hormones such as growth hormone.

Our studies confirm the high incidence of antibodies to some of the contaminants of insulin (proinsulin and PP) in patients treated with conventional beef insulin [7,8]. Several hormonal contaminants known to be present are not so immunogenic; only two of 30 patients formed antibodies to glucagon and none to somatostatin and VIP.

Variation of antibody binding of insulins of different species of origin has been described previously [9]. Proinsulin binding also varies with little correlation with insulin binding. Beef proinsulin binding exceeds pork proinsulin binding on average but in some subjects binding of pork proinsulin is higher than beef while binding of beef insulin may be higher than pork. When treatment is changed to a pure pork insulin the immunogenicity of the insulin appears less as the majority of patients have falling antibody titres

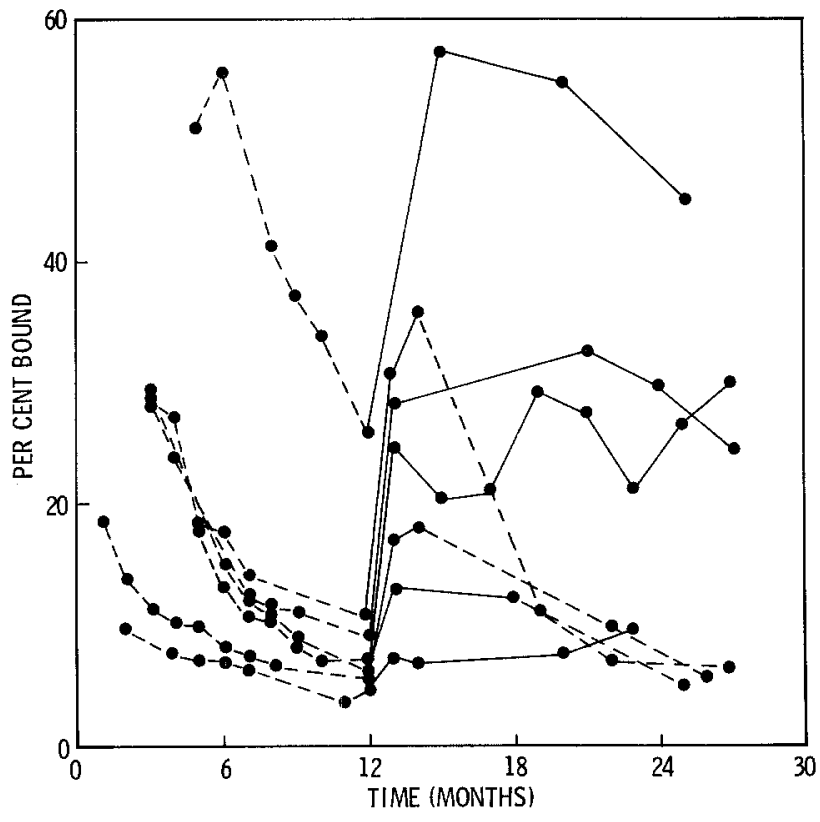

Fig. 2. Pancreatic polypeptide binding in seven subjects. The dashed line indicates treatment with highly purified pork insulin and the solid line treatment with conventional beef insulin. Initially each subject was on beef insulin and each study has been plotted so that the change back to beef insulin occurs at the same point on the graph. Results expressed as in Figure 1

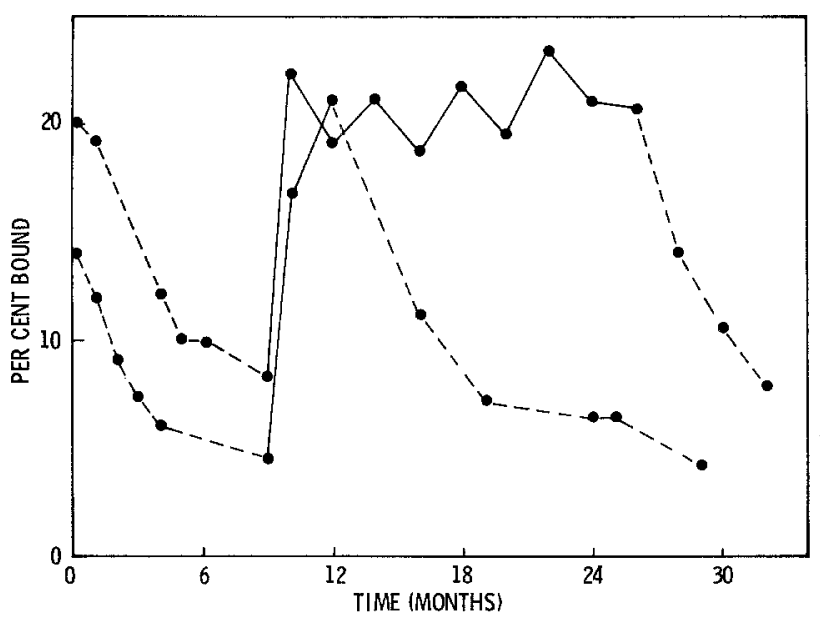

Fig. 3. Glucagon binding in two subjects. The dashed line indicates treatment with highly purified pork insulin and the solid line treatment with conventional beef insulin. Results expressed as in Figure 1

as has been previously reported $[8,13]$. The explanation must be either that the insulin itself is less immunogenic or that the reduction in concentration of insulin-like contaminants reduces an adjuvant effect; the latter seems unlikely given the low concentration of the contaminants in even the least pure insulins. Reduced immunogenicity of the insulin itself could be caused by the different species of origin, although it has been reported that pure beef and pork 
insulins can both be non-immunogenic [14] or by a decrease in the concentration of polymerised or altered insulin.

The low concentration of contaminating hormones seems a sufficient explanation for the low immunogenicity, in the highly purified pork insulin preparations, of the hormonal contaminants themselves. Patients treated only with purified pork insulin had no detectable antibodies to proinsulin, PP, glucagon, VIP and somatostatin. In our study a change to purified pork insulin was followed by a considerable decrease in antibody binding of insulin to levels similar to those found in patients only ever exposed to pure pork insulin, and by a decrease in antibody binding of proinsulin, PP and glucagon. These patients are however immunised and readministration of the immunogen, such as occurred with a change back to conventional beef insulin, resulted in a secondary immune response.

It appears that the proinsulin and contaminating hormone concentrations in purified pork insulin during the period of this study (1975-1978) were low enough to be non-immunogenic and the concentrations are probably even lower now: it may well not be worth pursuing further increases of purity. The insulin dose reduction which we observed need not be related to the antibody changes and in any case can only be evaluated accurately in relation to glycaemic regulation. In the group we studied the antibody titres were moderate and antibody related dose reduction has usually been reported in patients with high initial antibody titres $[12,13]$ or a large difference in antibody binding of beef and pork insulin [9, 15]. Initial studies indicate a lower initial activity of beef insulin compared with pork insulin in some patients which cannot be explained by insulin binding to antibody [16].

Acknowledgements. This study was generously supported by a grant from Nordisk Insulinlaboritorium. We also gratefully acknowledge the gift of reagents by Novo Laboratories Ltd. and Nordisk Diagnostics Ltd.

\section{References}

1. Chance RE, Root MA, Galloway JA (1976) The immunogenicity of insulin preparations. Acta Endocrinol (Kbh) 83: $185-195$
2. Bloom SR, West AM, Polak JM, Barnes AJ, Adrian TE (1978) Hormonal contaminants of insulin. In: Bloom SR, Grossman MI (ed), Gut hormones. Churchill Livingstone, Edinburgh, p 318-322

3. Karonen S-L, Mörsky P, Siren M, Seuderling U (1975) An enzymatic solid phase method for trace iodination of proteins and peptides with ${ }^{125}$ Iodine. Anal Biochem 67: 1-10

4. Melani F, Rubenstein AH, Steiner DF (1970) Human serum proinsulin. J Clin Invest 49: 497-507

5. Kumar D, Miller LV (1973) The prevalence of proinsulin specific antibodies in diabetic patients. Horm Metab Res 5: $1-3$

6. Desbuquois D, Aurbach GD (1971) Use of polyethylene glycol to separate free and antibody bound peptide hormones in radioimmunoassays. J Clin Endocrinol Metab 33: 732-738

7. Bloom SR, Adrian TE, Barnes AJ, Polak JM (1979) Autoimmunity in diabetics induced by hormonal contaminants of insulin. Lancet I: $14-16$

8. Bruni B, Gama S, Regis G, Turco GL (1978) Proinsulin and A-component antibodies in diabetics after long term monocomponent insulin. Diabetologia 14: 165-169

9. Kurtz AB, Matthews JA, Nabarro JDN (1978) Insulin-binding antibody: reaction differences with bovine and procine insulins. Diabetologia 15: 19-22

10. Andreani D, Lavicoli M, Tamburrano G, Menzinger G (1974) Comparative trials with monocomponent (MC) and monospecies (MS) pork insulins in the treatment of diabetes mellitus. Horm Metab Res 6: 447-454

11. Oakley NW (1976) Effect of "fractionated" insulins on total plasma insulin binding capacity and insulin requirement in severe diabetes. Lancet I: 994-996

12. Mustaffa BE, Daggett PR, Nabarro JDN (1977) Insulin binding capacity in patients changed from conventional to highly purified insulins. Diabetologia 13: 311-315

13. Asplin CM, Hartog M, Goldie DJ (1978) Change of insulin dosage, circulating free and bound insulin and insulin antibodies on transferring diabetics from conventional to highly purified porcine insulin. Diabetologia 14: 99-105

14. Schlichtkrull J, Brange J, Christiansen $\mathrm{AH}$, Hallund $\mathrm{O}$, Heding LG, Jorgensen KH (1972) Clinical aspects of insulinantigenicity. Diabetes 21: 649-656

15. Devlin JG, Parameswaran V (1976) Highly purified insulins. Lancet I: 1355

16. Alberti KGMM, Nosadini R, Noy G, Kurtz AB (1979) Differential response of insulin-dependent diabetics to infusions of bovine and highly-purified porcine insulins. A preliminary report. Adv Exp Med Biol 119: 329-325

Received: March 12, 1979 , and in revised form: September 5, 1979

Dr. A. B. Kurtz

Department of Nuclear Medicine

The Middlesex Hospital

Mortimer Street

London W1N 8AA

England 